\title{
Hydrologic and chemical control of Phragmites growth in tidal marshes of SW Connecticut, USA
}

\author{
Randolph M. Chambers ${ }^{1, *}$, David T. Osgood ${ }^{2}$, Ned Kalapasev ${ }^{3}$ \\ ${ }^{1}$ Department of Biology and Virginia Institute of Marine Science, College of William and Mary, PO Box 8795, Williamsburg, \\ Virginia 23187, USA \\ ${ }^{2}$ Biology Department, Albright College, PO Box 15234, Reading, Pennsylvania 19612, USA \\ ${ }^{3}$ Department of Biology and Environmental Sciences, University of New Haven, 300 Orange Avenue, West Haven, \\ Connecticut 06516, USA
}

\begin{abstract}
We compared hydrology and porewater chemistry along transects in 3 tidal marshes vegetated by Spartina alterniflora and by the invasive species Phragmites australis. Relative to the Phragmites zone, the $S$. alterniflora zone occurred at lower tidal elevations in all 3 marshes and was characterized by greater depth of flooding and shorter periods of water-table drawdown below the soil surface. Penetration by Phragmites into the $S$. alterniflora zone appeared to be limited by extensive soil saturation at the leading edge of Phragmites growth. This mixed-species zone occurred at the intersection of the low-tide groundwater table with the soil surface and was characterized by significantly higher concentrations of porewater sulfide $(739 \pm 63 \mu \mathrm{M})$ relative to the monospecific Phragmites zone $(335 \pm 63 \mu \mathrm{M})$. Dissolved ammonium and phosphate concentrations were also significantly lower in the Phragmites zone relative to $S$. alterniflora and mixed-species zones of vegetation. Discriminant analysis of the measured hydrologic and chemical variables identified depth of flooding, flooding frequency and duration, and sulfide concentration, as the most significant variables distinguishing Phragmites stands along the estuarine salinity gradient. Together, these results indicate a greater flooding tolerance by Phragmites in marshes where porewater sulfide and salinity are lower. From a hydrologic and chemical perspective, opportunities for Phragmites invasion and expansion should be greater in oligohaline and mesohaline tidal marshes relative to polyhaline habitats. To control the growth of Phragmites in tidal marshes of management concern, both the feasibility and need for methods that increase flooding depth, frequency, salinity and/or sulfide concentrations should be considered.
\end{abstract}

KEY WORDS: Phragmites $\cdot$ Spartina $\cdot$ Hydrology $\cdot$ Salinity $\cdot$ Sulfide $\cdot$ Porewater

Resale or republication not permitted without written consent of the publisher

\section{INTRODUCTION}

Over the past $50 \mathrm{yr}$, expansion of common reed Phragmites australis into oligohaline and mesohaline tidal marshes of the USA has led to dramatic changes in plant community structure and, perhaps, wetland function (Roman et al. 1984, Chambers et al. 1999, Windham \& Lathrop 1999, Meyerson et al. 2000, War-

*E-mail: rmcham@wm.edu ren et al. 2001). Plant and animal diversity is diminished in Phragmites wetlands relative to the wetlands they replace (Marks et al. 1994, Benoit \& Askins 1999), and specific habitat function (i.e. spawning and nursery use by fish and macrocrustaceans) may be impaired (Weinstein \& Balletto 1999, Able \& Hagan 2000, Osgood et al. in press). Because of these concerns, enhanced saltwater flooding of reed-dominated wetlands is used as a management tool to limit Phragmites expansion, but the specific mechanism for controlling reed growth has never been identified. Further, man- 
agement efforts sometimes are not successful, and reasons for success or failure cannot always be documented. Finally, Phragmites expansion continues even in some tidally unrestricted marshes, so the need exists for understanding the specific environmental factors that influence reed establishment and expansion in these wetlands (Bart \& Hartman 2000).

Hydrology, specifically periodic fluctuation in water level, is the primary determinant of vegetation community structure and ecosystem function in both tidal and non-tidal wetlands (Gosselink \& Turner 1978, Odum et al. 1995). Differences in nutrient status, oxygen content and salinity of the soil are often reported as the mechanisms that link hydrologic pulses to the vegetation structure of the wetland ecosystem. For example, the production of the tidal marsh grasses has been linked to porewater drainage through the alleviation of salt accumulation, excess hydrogen sulfide concentrations and low oxygen status of the soil (Chalmers 1982, Howes et al. 1986). More recently, the occurrence and growth of plant species in lower-salinity marshes has also been linked to factors including soil saturation and soil chemistry (Burdick et al. 1989, Koch \& Mendelssohn 1989, Koch et al. 1990, Broome et al. 1995).

Similar feedbacks between plants and the wetland soil environment (Bertness 1992) may facilitate the establishment and spread of Phragmites along the estuarine salinity gradient (Amsberry et al. 2000, Bart \& Hartman 2000, Warren et al. 2001). Low porewater nutrient concentrations within Phragmites peat have been attributed to substantial storage of nutrients in aboveground tissue (Templer et al. 1997, Meyerson et al. 2000) and higher rates of denitrification within irregularly flooded Phragmites stands (Chambers et al. 1998). Phragmites also has the capacity to oxidize the rhizosphere (Bart \& Hartman 2000). How soil chemistry within Phragmites stands interacts with hydrology, and the extent to which these interactions affect expansion rates along the estuarine salinity gradient is still unknown. From a management perspective, identification of the range of environmental conditions where Phragmites occurs may assist both the identification of tidal wetlands susceptible to further expansion and the development of methods for limiting Phragmites spread (Chambers et al. 1998).

We hypothesize that the linkage between hydrology and soil biogeochemistry is a primary determinant of Phragmites expansion in tidal marshes. Increased growth and competitive abilities in Phragmites and its recent expansion into tidal marshes in part may be due to genetic hybridization
(Clevering \& Lissner 1999, Koppitz 1999), but the physical and biological environment still imposes limitations on the realized niche of salt marsh vegetation (e.g. Emery et al. 2001). In this paper, we compare the hydrology and porewater chemistry of 3 tidal salt marshes occurring along an estuarine salinity gradient to help identify the environmental limits of Phragmites expansion into Spartina alterniflora marshes.

\section{MATERIALS AND METHODS}

Study site. Three fringing marshes were chosen for study along the estuarine salinity gradient of the lower Housatonic River in SW Connecticut $\left(41^{\circ} 10.3^{\prime} \mathrm{N}, 73^{\circ} 6.34^{\prime} \mathrm{W}\right)$ (Table 1 ). In each marsh, 3 short $(<30 \mathrm{~m})$ transects 10 to $30 \mathrm{~m}$ apart extended from a zone of higher tidal elevation dominated by Phragmites, across a mixed-species marsh zone co-dominated by Phragmites and Spartina alterniflora, to a lower-elevation, tidal creek zone dominated by $S$. alterniflora. Standard surveying techniques were used to determine marsh elevations in each vegetation zone relative to the creekbank edge of the $S$. alterniflora zone. Through analysis of 1:2400 aerial photographs from 1995 using Arcview 3.2a, we determined that expansion by Phragmites was greater with distance up the estuary, as documented by the decreasing percentage of $S$. alterniflora area in the marshes located 4,6 and $8 \mathrm{~km}$ from where the river discharges into Long Island Sound (Table 1). These distribution patterns were visible on aerial photography as far back as 1950, indicating early establishment and relative stability of the Phragmites stands under study.

Hydrologic instrumentation and analysis. Piezometers constructed of $5 \mathrm{~cm}$ diameter PVC pipe, commercially slotted over a $10 \mathrm{~cm}$ length at the bottom of the pipe, were installed to $30 \mathrm{~cm}$ soil depth in Phragmites, mixed-species and Spartina alterniflora vegetation zones along each transect $(n=27)$. Hydraulic head was continuously monitored for a 2 wk interval encompass-

Table 1. Location of 3 tidal salt marshes near the mouth of the Housatonic River in SW Connecticut, USA, showing the average porewater salinity and relative area of the Spartina zone and elevations of the mixed-species and Phragmites zones in each marsh

\begin{tabular}{|lcccc|}
\hline $\begin{array}{l}\text { Distance from } \\
\text { mouth of river }\end{array}$ & $\begin{array}{c}\text { Average salinity (SD) } \\
\text { April 1999 (ppt) }\end{array}$ & \multicolumn{3}{c|}{$\begin{array}{c}\text { Average elevation } \\
\text { relative to } \\
\text { Spartina zone (cm) }\end{array}$} \\
\hline $8 \mathrm{~km}$ & $8.4(1.8)$ & 0.7 & 20.6 & 41.2 \\
$6 \mathrm{~km}$ & $11.7(2.1)$ & 12 & 24.7 & 32.4 \\
$4 \mathrm{~km}$ & $19.0(7.0)$ & 92 & 42.3 & 74.6 \\
\hline
\end{tabular}


ing both spring and neap tidal phases each month from July to September 1998 and April to August 1999 by instrumenting each piezometer with a mini-data logger/pressure transducer unit (Onset Computer) set to record pressure at 12 min time intervals. This dataset represents a total of 11 neap and 13 spring tide periods over the course of the study. Individual pressure readings recorded by the transducer were converted to hydraulic head by calibrating each instrument with measurements of actual water level in the piezometers, concurrent with pressure recordings. Hydraulic head was determined by referencing all converted pressure measurements to a common datum $1 \mathrm{~m}$ below the marsh surface. Resolution of the pressure transducer/ data loggers was within $1.3 \mathrm{~cm}$. Water level from the piezometers is reported as the average water table maximum and minimum relative to the marsh surface for each recorded tidal cycle (28 recorded cycles $\mathrm{mo}^{-1}$ ).

The specific yield (water drainage per unit volume) of soils from Phragmites and Spartina alterniflora zones was determined by measuring head changes following addition of a known volume of water to a dewatered, $30 \mathrm{~cm}$ diameter by $30 \mathrm{~cm}$ deep core (Harvey et al. 1995). One core each was collected from $S$. alterniflora and Phragmites zones at each marsh, using sharpened teeth on the corer to minimize compaction to less than $1 \mathrm{~cm}$. From piezometer measurements, the maximum change in hydraulic head over both the ebb and flood portion of the tidal cycle $(\Delta H)$ was multiplied by specific yield $\left(S_{\mathrm{y}}\right)$ to calculate the total volume of porewater exchanged with each tide. This value was then divided by $12 \mathrm{~h}$ to determine the porewater flow rate $(Q)\left(1 \mathrm{~m}^{-2}\right.$ tide $\left.^{-1}\right)$, as:

$$
Q=\left[S_{\mathrm{y}} \times\left(\Delta H \times 1 \mathrm{~m}^{2}\right)\right] / 12 \mathrm{~h}
$$

Porewater flow rate therefore represented the total volume of flow through the root zone in a single tidal cycle as a function of soil properties and head changes associated with tidal and evapotranspirative fluxes. Raw data satisfied the assumptions of normality and homogeneity of variance. Significant differences in mean porewater flow rates, water table position and specific yield among marshes and vegetation zones were identified using 2-way ANOVA.

Porewater collection and analysis. In each vegetation type along all transects, duplicate porewater samplers were installed to $30 \mathrm{~cm}(\mathrm{n}=54)$. Samplers consisted of slotted $3.8 \mathrm{~cm}$ PVC pipe with a porous bottom plate to minimize clogging; samplers were capped with a butyl rubber stopper to inhibit oxygen penetration. Once a month from April through October 1999, vertically integrated porewater samples were collected at low tide by pumping out the samplers and within $1 \mathrm{~h}$ withdrawing the water that refilled them. Water samples were passed by syringe through a Whatman GFC filter ( $1 \mu \mathrm{m}$ pore size) and processed immediately in the field. Porewater for sulfide analysis was filtered directly into vials containing mixed diamine reagent (Cline 1969); porewater for dissolved nutrients was acidified with $6 \mathrm{~N} \mathrm{HCl}$ to a $\mathrm{pH}<2$ and kept refrigerated. Porewater salinity was read directly in the field using a hand-held refractometer (accuracy \pm 1 ppt).

Dissolved sulfide, phosphate and ammonium analyses were completed spectrophotometrically using standard analytical techniques (Parsons et al. 1984). For nutrient analyses, the interference of sulfide with color development was removed by initially bubbling the acidified water samples with nitrogen gas, then adjusting the sample $\mathrm{pH}$ to neutrality with $6 \mathrm{~N} \mathrm{NaOH}$. Significant differences in porewater chemistry among marshes and zones of vegetation were identified using repeated measures ANOVA $(\mathrm{p}<0.05)$.

Plant collection and measurement. Before the flowering season in August 1999, stem density and plant height of Phragmites were determined in both Phragmites and mixed-species stands. Triplicate $0.25 \mathrm{~m}^{2}$ quadrats were selected at random adjacent to each sampling station, and the stem heights of all living shoots in the quadrats were measured.

Discriminant analysis. We used discriminant analysis to identify the measured hydrologic and chemical variables contributing most significantly to the occurrence of Phragmites in the 3 tidal marshes. Discriminant analysis generated a linear combination of the 4 hydrologic variables (water table maximum, water table minimum, flooding frequency and duration) and 4 chemical variables (porewater salinity, sulfide, ammonium and phosphate) that best explained the categorical separation of the dependent variable (Phragmites position) along the estuarine salinity gradient of the lower Housatonic River estuary.

\section{RESULTS}

\section{Hydrologic analysis}

The $2 \mathrm{wk}$ continuous recording of water table levels demonstrated the differences in tidal flooding among zones of vegetation (Fig. 1). For the lower 2 sites, at 4 and $6 \mathrm{~km}$, the water table position in the Phragmites zone remained below the soil surface during neap tides and moved above the soil surface only during the spring tidal phase. For the upper $8 \mathrm{~km}$ site, the Phragmites zone was flooded almost every tidal cycle. The Spartina alterniflora zone was flooded every tidal cycle in every marsh, but tidal excursions in the water table were large, i.e. the soils drained regularly. In contrast, water table position in the mixed-species zone tended to remain nearer or above the soil surface throughout 

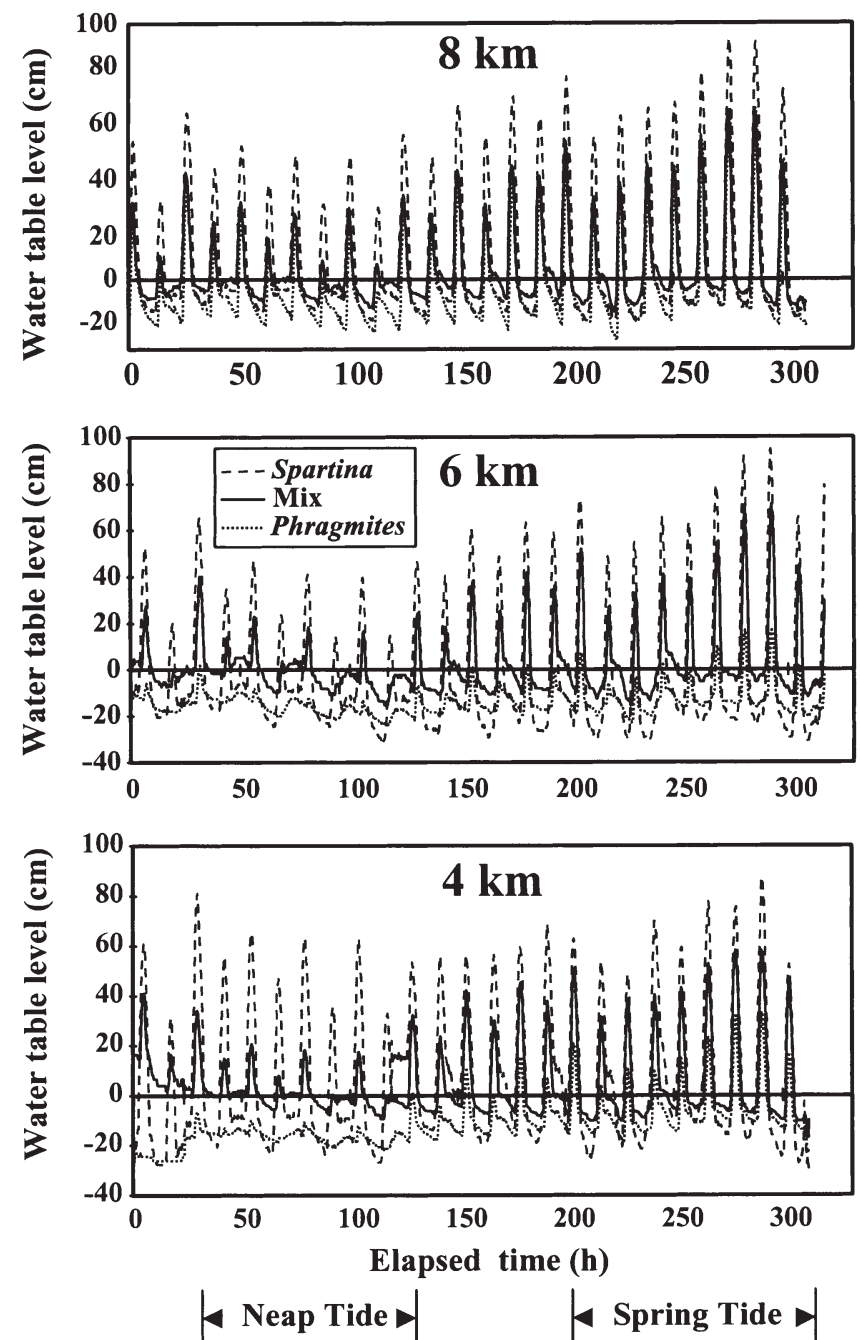

Fig. 1. Continuous recordings of water table levels from 22 July to 5 August 1998 as measured from piezometers within each vegetation zone at each marsh site. A water table value of 0 corresponds with the marsh surface neap and spring tidal cycles, demonstrating a greater time of soil waterlogging.

Averaged over all measured tidal cycles, the mean minimum position of the water table at low tide was significantly higher in the mixed-species zone relative to both Phragmites and Spartina alterniflora zones (Fig. 2). A larger portion of the plant rhizosphere remained waterlogged during the entire tidal cycle in the mixed-species zones relative to both Phragmites zones (occurring at higher elevations) and $S$. alterniflora zones (occurring at lower elevations). Commensurate with relative elevations (Table 1), the mean maximum flooding depth was greatest in S. alterniflora zones, less in mixed-species zones and least in Phragmites zones. The maximum depth of flooding in the Phragmites zone was greatest in the $8 \mathrm{~km}$ marsh located farthest up the estuary (Fig. 2).

Within each marsh, the Phragmites zone typically flooded less frequently and for a shorter duration of the tidal cycle than the Spartina alterniflora and mixedspecies zones (Table 2). Also, porewater flow rate was less in the Phragmites zone relative to the $S$. alterniflora zone in all marshes. Comparing Phragmites zones among marshes, however, porewater flow rate was greatest in the $8 \mathrm{~km}$ marsh relative to both the 4 and $6 \mathrm{~km}$ marshes. The higher flow rate from the $8 \mathrm{~km}$ marsh occurred despite a lower specific yield, underscoring the influence of the larger tidal excursion at that marsh (Fig. 2). Flooding frequency, but not duration, was also greatest in the Phragmites zone of the $8 \mathrm{~km}$ marsh (Table 2).

\section{Porewater analysis}

Among marshes, porewater salinity ranged from 5 to 25 ppt over the course of the study. We documented

Table 2. Summary of hydrologic variables, expressed as mean (SE) for Phragmites (P), mixed-species (M) and Spartina (S) zones of vegetation in each marsh along the estuarine salinity gradient. na = not available

\begin{tabular}{|c|c|c|c|c|c|c|c|c|c|}
\hline \multirow[t]{2}{*}{ Variable } & \multicolumn{3}{|c|}{$4 \mathrm{~km}$} & \multicolumn{3}{|c|}{$6 \mathrm{~km}$} & \multicolumn{3}{|c|}{$8 \mathrm{~km}$} \\
\hline & $\mathrm{P}$ & $\mathrm{M}$ & $\mathrm{S}$ & $P$ & $\mathrm{M}$ & $\mathrm{S}$ & $\mathrm{P}$ & $\mathrm{M}$ & $\mathrm{S}$ \\
\hline Flooding frequency $(\%)^{\mathrm{a}}$ & $64.0(6.8)^{\mathrm{e}, \mathrm{f}}$ & $91.1(2.8)$ & $99.8(0.2)$ & $58.0(4.8)^{\mathrm{e}, \mathrm{f}}$ & $87.6(1.8)$ & $98.7(0.7)$ & $89.7(2.3)^{\mathrm{e}, \mathrm{f}}$ & $93.3(1.7)$ & $99.6(0.4)$ \\
\hline Flooding duration $(\%)^{\mathrm{b}}$ & $16.6(2.4)^{\mathrm{e}}$ & $24.7(2.3)$ & $40.9(2.7)$ & $19.7(4.0)^{\mathrm{e}}$ & $28.7(4.2)$ & $30.7(1.6)$ & $21.8(2.1)^{\mathrm{e}}$ & $35.3(3.8)$ & $36.9(2.8)$ \\
\hline $\begin{array}{l}\text { Porewater flow rate } \\
\left(\mathrm{l} \mathrm{m}^{-2} \text { tidal cycle }{ }^{-1}\right)^{\mathrm{c}}\end{array}$ & $19.0(0.8)^{\mathrm{e}, \mathrm{f}}$ & na & $60.7(0.9)$ & $17.0(0.6)^{\mathrm{e}, \mathrm{f}}$ & na & $46.0(0.7)$ & $31.2(0.6)^{\mathrm{e}, \mathrm{f}}$ & na & $52.9(0.8)$ \\
\hline $\begin{array}{l}\text { Specific yield } \\
\left(\mathrm{cm}^{3} \mathrm{~cm}^{-3}\right)^{\mathrm{d}}\end{array}$ & $0.28(0.12)^{\mathrm{f}}$ & na & $0.14(0.03)$ & $0.07(0.02)$ & na & $0.05(0.01)$ & $0.03(0.01)$ & na & $0.07(0.03)$ \\
\hline \multicolumn{10}{|c|}{$\begin{array}{l}{ }^{\mathrm{a}} \text { Expressed as percentage of recorded high tide events }\left(28 \mathrm{mo}^{-1}\right) \text { when marsh was flooded, } \mathrm{n}=8 \\
{ }^{\mathrm{b}} \text { Expressed as percentage of tidal cycle }(12 \mathrm{~h}) \text { that marsh was flooded, } \mathrm{n}=224 \\
{ }_{\mathrm{c}} \mathrm{n}=112 \text {, the number of complete tidal cycles } \\
{ }^{\mathrm{d}} \mathrm{n}=5 \text { replicates per core } \\
{ }^{\mathrm{e}} \text { Indicates significant difference from mixed and Spartina stands at the same site, ANOVA, } \mathrm{p}<0.05 \\
{ }^{\mathrm{f}} \text { Indicates significant difference from Phragmites stands at other sites, ANOVA, }<0.05\end{array}$} \\
\hline
\end{tabular}




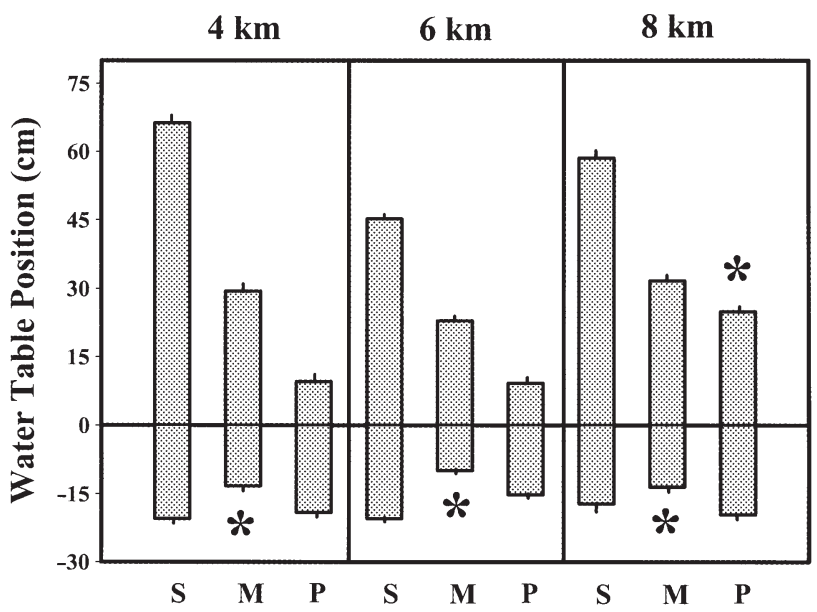

Fig. 2. Summary of water table excursions in each vegetation type, presented as the mean maximum (above 0) and minimum (below 0) water table positions relative to the marsh surface at each site. Means plus SE are the average of 28 tidal events each month from July to September 1998 and April to August 1999. Water table maxima are significantly different among vegetation types within marshes (ANOVA, $\mathrm{p}<0.01$ ). Between marshes, the water table maximum in the Phragmites zone is significantly higher at the $8 \mathrm{~km}$ marsh, noted with an asterisk. The water table minimum in the mixedspecies vegetation zone was significantly higher than Spartina and Phragmites zones of each marsh, noted with an asterisk
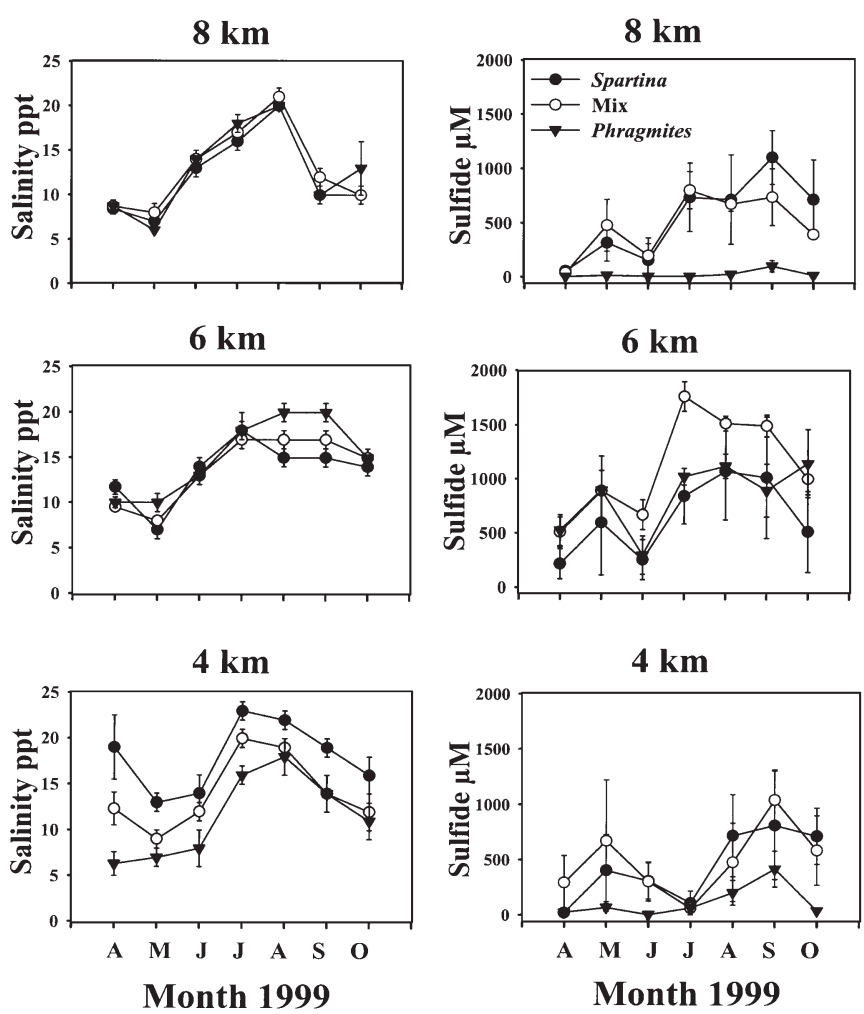

Fig. 3. Average monthly porewater salinity and sulfide concentration by vegetation zone from each marsh over the 1999 growing season, $\pm \mathrm{SE}(\mathrm{n}=6)$ strong monthly differences in porewater salinity, typically with lowest values measured in April and highest values in July or August (Fig. 3). Relative to the Spartina alterniflora zone, lower salinity in the Phragmites and mixed-species zones of the $4 \mathrm{~km}$ marsh was observed and may have been due to intrusion of fresh groundwater near the upland margin. Porewater sulfide concentration ranged from 0 to $1500 \mu \mathrm{M}$ and was always lower in the Phragmites zone relative to the other vegetation zones in all 3 marshes along the estuarine salinity gradient (Fig. 3). From the $6 \mathrm{~km}$ marsh, sulfide concentration in the Phragmites zone was on average $>500 \mu \mathrm{M}$ for 5 of the 7 months sampled, whereas the average sulfide concentration was $<500 \mu \mathrm{M}$ for every month from the 4 and $8 \mathrm{~km}$ marshes.

Porewater ammonium and phosphate concentrations ranged from 3 to $75 \mu \mathrm{M}$ and 2 to $35 \mu \mathrm{M}$, respectively, and generally were lower in the Phragmites zone of vegetation (Fig. 4). The broadest differences in concentrations among vegetation zones were observed in porewater from the $8 \mathrm{~km}$ marsh. On average, the highest porewater ammonium concentration measured in August $(50.5 \pm 8.3 \mu \mathrm{M})$ was 5 times higher than the lowest concentration in April $(9.5 \pm 2.1 \mu \mathrm{M})$; whereas the highest phosphate concentration measured in May $(20.6 \pm 2.5 \mu \mathrm{M})$ was more than double the lowest concentration in April $(8.3 \pm 1.0 \mu \mathrm{M})$.

Repeated measures ANOVA revealed significant differences in the concentrations of porewater constituents by marsh ( $\mathrm{df}=2, \mathrm{p}<0.01)$ and/or by vegetation type $(\mathrm{df}=2, \mathrm{p}<0.01)$. Significant interactions between marsh and vegetation type were found for salinity, sulfide and phosphate concentration. We completed a posteriori, mean comparisons between treatment groups to determine the sources of significant variation in salinity, sulfide, ammonium and phosphate (Table 3). Among marshes, mean salinity was slightly lower and phosphate was higher at the $8 \mathrm{~km}$ site relative to the 4 and $6 \mathrm{~km}$ marshes. Ammonium concentration was not significantly different among marshes, but sulfide concentration was significantly higher at the $6 \mathrm{~km}$ marsh. Among vegetation zones, salinity was slightly higher in the Spartina alterniflora zone, but sulfide concentration was highest in the mixed-species zone. Both ammonium and phosphate concentrations were lower in the Phragmites zone, with similarly higher concentrations in the mixed-species and $S$. alterniflora zones.

\section{Analysis of plant metrics}

At both the 4 and $6 \mathrm{~km}$ marshes, the mean number of reed stems $( \pm \mathrm{SE}) \mathrm{m}^{-2}$ between Phragmites and mixed-species stands was not significantly different 
Table 3. Multiple a posteriori comparisons of significant differences in porewater chemistry variables between marshes and zones of vegetation (Tukey's HSD, $\mathrm{p}<0.05)$. Groups with statistically similar means (SE) have the same superscript(s) $(\mathrm{n}=18)$

\begin{tabular}{|c|c|c|c|c|c|c|}
\hline \multirow{2}{*}{ Variable } & \multicolumn{3}{|c|}{ Marsh } & \multicolumn{3}{|c|}{ Vegetation zone } \\
\hline & $4 \mathrm{~km}$ & $6 \mathrm{~km}$ & $8 \mathrm{~km}$ & Phragmites & Mix & Spartina \\
\hline Salinity & $14.2(0.3)^{\mathrm{a}}$ & $14.0(0.2)^{\mathrm{a}}$ & $12.7(0.2)^{\mathrm{b}}$ & $13.2(0.2)^{\mathrm{a}}$ & $13.4(0.2)^{\mathrm{a}}$ & $14.3(0.2)^{\mathrm{b}}$ \\
\hline Sulfide & $389(72)^{a}$ & $870(61)^{\mathrm{b}}$ & $404(64)^{\mathrm{a}}$ & $335(63)^{a}$ & $739(63)^{\mathrm{b}}$ & $589(69)^{a, b}$ \\
\hline Ammonium & $20.7(4.4)^{\mathrm{a}}$ & $26.8(3.6)^{\mathrm{a}}$ & $26.6(3.7)^{\mathrm{a}}$ & $12.6(3.7)^{\mathrm{a}}$ & $35.4(3.8)^{\mathrm{b}}$ & $26.1(4.3)^{\mathrm{a}, \mathrm{b}}$ \\
\hline Phosphate & $9.9(1.9)^{\mathrm{a}}$ & $11.3(1.5)^{\mathrm{a}}$ & $16.1(1.6)^{b}$ & $7.4(1.5)^{\mathrm{a}}$ & $14.2(1.5)^{\mathrm{b}}$ & $15.7(2.0)^{\mathrm{b}}$ \\
\hline
\end{tabular}
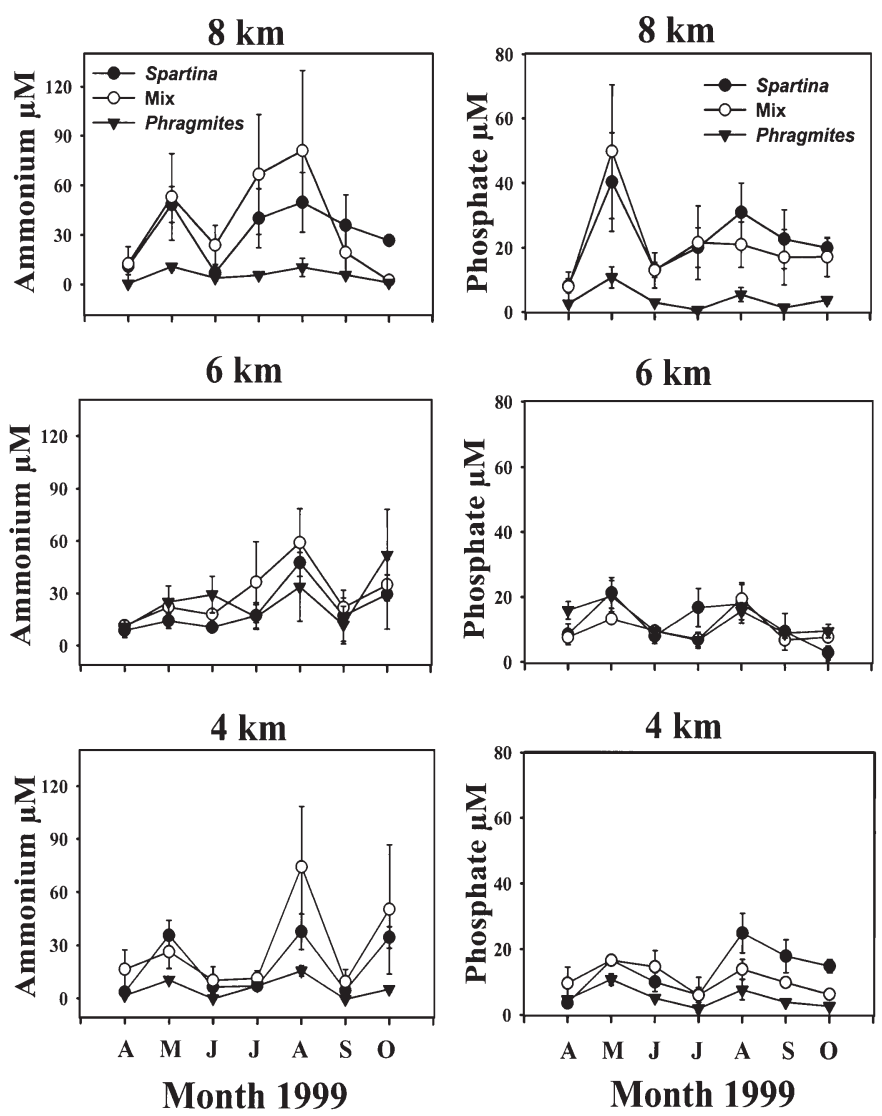

Fig. 4. Average monthly porewater ammonium and phosphate concentration by vegetation zone from each marsh over the 1999 growing season, \pm SE $(n=6)$

$(38.7 \pm 4.7$ vs $36.7 \pm 6.7$ and $49.3 \pm 6.2$ vs $51.6 \pm 6.8$, respectively), but at the $8 \mathrm{~km}$ marsh farthest up the estuary, significantly more stems were found in the Phragmites stands relative to the mixed-species stands $(48.4 \pm 8.1$ vs $26.7 \pm 3.1 ; \mathrm{n}=9, t$-test, $\mathrm{p}<0.05)$. Stem heights measured during the growing season were different between marshes and zones of vegetation. At both the 4 and $8 \mathrm{~km}$ marshes, Phragmites stems (mean height $[ \pm \mathrm{SE}] \mathrm{m}$ ) were significantly taller in the Phragmites stands relative to the mixed-species

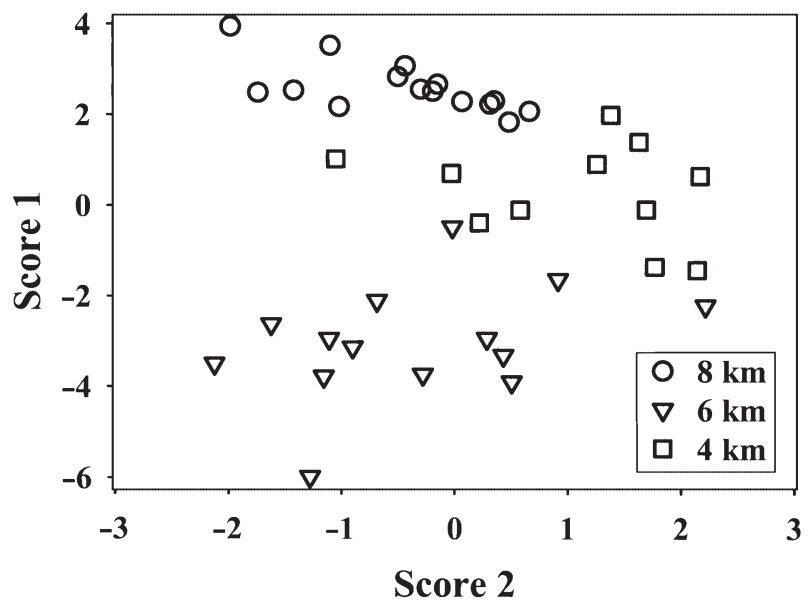

Fig. 5. Canonical variates scores from discriminant analysis of Phragmites zones of vegetation along the estuarine salinity gradient as a function of hydrology and porewater chemistry variables

stands $(2.3 \pm 0.1$ vs $1.3 \pm 0.1$ and $2.2 \pm 0.1$ vs $1.4 \pm 0.1$, respectively; $\mathrm{n}=9, t$-test, $\mathrm{p}<0.05)$. At the mid-salinity site, the plants were uniformly short and not different between Phragmites and mixed-species stands (1.3 \pm 0.1 vs $1.0 \pm 0.1)$.

\section{Discriminant analysis}

Significant discrimination among Phragmites zones of the marshes along the estuarine salinity gradient of the lower Housatonic River was accomplished by the first loading factor in the analysis $(93 \%, p<0.001$; Fig. 5). The independent variables contributing most strongly to this separation were maximum water table depth, flooding frequency and duration (hydrologic variables), and porewater sulfide concentration (a chemical variable) (Table 4). Canonical coefficients for water table minimum, porewater salinity, ammonium and phosphorus concentrations were smaller. The second loading factor was not significant to the discriminant analysis $(\mathrm{p}=0.07)$. 
Table 4. Standard canonical coefficients from discriminant analysis

\begin{tabular}{|lcc|}
\hline Variable & \multicolumn{2}{c|}{ Canonical variates } \\
& $\begin{array}{c}\text { Variate } 1 \\
(93 \%) \mathrm{p}<0.001\end{array}$ & $\begin{array}{c}\text { Variate } 2 \\
(7 \%) \mathrm{p}=0.07\end{array}$ \\
\hline Water table maximum & 0.97 & -1.81 \\
Water table minimum & -0.09 & -0.46 \\
Flooding duration & -0.79 & 1.99 \\
Flooding frequency & 0.79 & -0.17 \\
Porewater salinity & 0.57 & -0.46 \\
Sulfide & -1.03 & -0.24 \\
Ammonium & -0.35 & 0.00 \\
Phosphate & -0.06 & -0.22 \\
& & \\
\hline
\end{tabular}

\section{DISCUSSION}

With the current expansion of Phragmites into tidal marshes of North America, research efforts are focused on identifying methods for controlling reed growth (Chambers et al. 1999). Our approach was to determine hydrologic and chemical conditions of soil environments along both an estuarine salinity gradient and a vegetation gradient through marsh zones dominated by a native species (Spartina alterniflora) and the invasive Phragmites australis. Edaphic conditions that are modified by marsh management or restoration may preclude the expansive growth of Phragmites.

Relative to the Spartina alterniflora zone of the low marsh, lower flooding depth, reduced porewater flow rate, and lower flooding frequency and duration were the hydrological characteristics of the Phragmites zone of the high marsh. Interestingly, we observed low water table minima for both the Phragmites zone (at high tidal elevation with longer exposure) and $S$. alterniflora zone (at low tidal elevation and shorter exposure). Water table drawdown in soils of the more frequently flooded $S$. alterniflora zone probably was due to high rates of horizontal porewater drainage typically found within 10 to $15 \mathrm{~m}$ of the creek edge in tidal marshes (Harvey et al. 1987); each of our S. alterniflora sampling locations was within $5 \mathrm{~m}$ of a marsh creek. In contrast, the low-tide water table position was highest in the mixed-species zone where the water table intersected with the marsh surface (Fig. 2).

Significant variation in 3 hydrologic variables helped distinguish among Phragmites stands along the estuarine salinity gradient (Table 4). In the discriminant analysis, the standard canonical coefficients of the first loading factor for water table maximum and flooding frequency were positive owing to high values measured from the $8 \mathrm{~km}$ marsh. Flooding duration, however, was not higher at the $8 \mathrm{~km}$ marsh and thus had a negative canonical coefficient. Without absolute eleva- tions among the 3 marshes, we cannot compare tidal elevations of Phragmites zones, although a higher elevation might be inferred for the $6 \mathrm{~km}$ marsh where flooding frequency and water table maximum were low. The observed slow drainage from the $6 \mathrm{~km}$ marsh may have been a function of the low slope of the marsh surface being sufficient to counteract a shorter flooding duration (Table 1).

Consistent with the results of Bart \& Hartman (2000), the principal chemical factor influencing the expansion of Phragmites in tidal marshes appears to be porewater sulfide (Fig. 3). Sulfide concentrations were very low in the Phragmites zones of the 4 and $8 \mathrm{~km}$ marsh; elevated sulfide concentrations were more typical of mixed-species zones where the transition to Spartina alterniflora occurred. In addition to the probable effects of interspecific competition (Levine et al. 1998), physiological limits to Phragmites growth imposed by hydrology and porewater chemistry were apparently reached in mixed-species zones. From the discriminant analysis, the standard canonical coefficient for the independent variable of porewater sulfide concentration was negative, i.e. occurrence of Phragmites farthest up the estuary was negatively associated with sulfide concentration (Table 4). S. alterniflora is more tolerant of elevated sulfide in the rhizosphere (Chambers et al. 1998) and thus maintains a zone of vegetation into which Phragmites cannot easily expand.

Elevated sulfide does not necessarily preclude Phragmites, as documented by its presence in the $6 \mathrm{~km}$ marsh, where depth-integrated sulfide concentrations reached $1000 \mu \mathrm{M}$ during the growing season (Fig. 3). We did observe, however, that shoot growth in the Phragmites zone was stunted in this marsh relative to the other marshes, where sulfide concentrations were much lower. Production of sulfide in the rhizosphere is a manifestation of extensive soil waterlogging that promotes sulfate reduction. This environmental condition is more typical of lower elevations in the intertidal profile. Thus, the combination of extensive waterlogging and sulfide accumulation in the porewater creates edaphic conditions that are not conducive to the expansive growth of Phragmites.

Given the large springtime difference in porewater salinity among zones of Spartina alterniflora (Table 1), we anticipated that variation in porewater salinity would be correlated with the distribution of Phragmites in the 3 tidal marshes. Over the time of the study, porewater salinity was significantly lower in the $8 \mathrm{~km}$ marsh farthest up the estuary and was significantly lower in the Phragmites zone of vegetation (Table 3), but the differences among marshes and vegetation zones were not dramatic. Further, salinity was not a strong primary loading factor associated with the occurrence of Phragmites (Table 4), and others have 
suggested that shallow porewater salinity is not always a reliable predictor of Phragmites distribution (Burdick et al. 2001). The Phragmites zone in the $8 \mathrm{~km}$ marsh, however, experienced deeper surface flooding, as documented by maximum water table depth and flooding frequency (Table 2). With distance up the estuary, we suspect that lower-salinity marshes are susceptible to greater Phragmites expansion into lower relative tidal elevations (Table 1). We did not separate salinity effects experimentally from other chemical and hydrologic factors, but many studies have documented that elevated salinity negatively influences the growth and physiology of Phragmites (Hellings \& Gallagher 1992, Lissner \& Schierup 1997, Chambers et al. 1998). Salinity in combination with environmental stresses associated with waterlogging appears to influence the depth of penetration of Phragmites into the intertidal profile of marshes.

In our study, Spartina alterniflora was found lower in the intertidal zone and was inundated by tidal water more frequently for longer periods of time. At low tide, however, the water table was closest to the soil surface in the mixed-species zone, i.e. the degree of soil saturation at low tide was greater than in the Phragmites and $S$. alterniflora zones (Fig. 2). The initial sites of establishment of Phragmites tend to be restricted to sections of brackish and salt marshes where sulfide concentrations are low, such as along exposed creekbanks (Bart \& Hartman 2000) and marsh-upland transitions (this study). As a result of the inhibitory effects of salinity and sulfide, Phragmites expansion in marshes near the mouth of estuaries takes on a more restricted linear growth form along marsh edges. In contrast, a common observation is that Phragmites expansion from initial sites of establishment forms circular patches of growth in all lateral directions - reminiscent of fungal cultures on a petri plate-in marshes far up the estuary, where salinity and sulfide concentrations are uniformly low (Warren et al. 2001). This differential configuration of Phragmites in the estuarine landscape will influence the extent of impaired functions among tidal marshes (e.g. nekton habitat use and nutrient exchange; Weinstein \& Balletto 1999).

Phragmites grows rapidly and draws down soil nutrients that are incorporated into plant biomass (Meyerson et al. 1999). Porewater nitrogen and phosphorus concentrations were significantly lower in Phragmites vegetation zones, perhaps due to plant growth (Table 3). Regular tidal drainage of soil porewater in the Phragmites zone and oxygen transport through the roots also allow for cyclical oxidation and reduction of the rhizosphere, thereby providing conditions for coupled nitrification/denitrificiation. Lower ammonium concentrations in soil water of Phragmites zones may be a consequence of all these processes. In the
Spartina alterniflora and mixed-species zones, where ammonium and sulfide concentrations were typically higher (Table 3), nitrification and nitrogen uptake are inhibited by high concentrations of sulfide (e.g. Joye \& Hollibaugh 1995, Chambers et al. 1998) and dissolved phosphorus is more mobile in the absence of iron oxide sorption (Chambers \& Odum 1990).

To sum up, wetland hydrology and biogeochemistry combine to create soil environments influencing the distribution and expansion of Phragmites in tidal marshes. These controlling variables are manifest in edaphic features of the rhizosphere, including soil anoxia, nutrient availability and sulfide toxicity. The relative 'ease' with which Phragmites has expanded into large areas of oligohaline and mesohaline marshes, and its restriction to upland edges and creekbank levees of polyhaline marshes are tied to hydrological features of depth and frequency of flooding and associated chemical features of porewater salinity and sulfide concentration. Likewise, the efficiency with which Phragmites has been removed from invaded wetlands via restoration and enhancement of tidal water exchange is tied to these same factors. As for any restoration effort, managers must consider the economic feasibility and ecological need for methods to limit the spread of Phragmites in tidal wetlands of concern.

Acknowledgements. Thanks to M. Hojnacki, L. Hurton, L. Millman, C. Vanderbeck, D. Jacobson, S. Pianka and J. Lewis for field and laboratory assistance, and to D. Bart and F. Montalto for helpful editorial comments. Principle funding for the project was provided by NOAA CT Sea Grant Award NA86RG0043.

\section{LITERATURE CITED}

Able KW, Hagan SM (2000) Effects of common reed (Phragmites australis) invasion on marsh surface macrofauna: response of fishes and decapod crustaceans. Estuaries 23: 633-646

Amsberry L, Baker MA, Ewanchuk PJ, Bertness MD (2000) Clonal integration and the expansion of Phragmites australis. Ecol Appl 10:1110-1118

Bart DJ, Hartman JM (2000) Environmental determinants of Phragmites australis invasion in a New Jersey salt marsh: an experimental approach. Oikos 89:59-69

Benoit LK, Askins RA (1999) Impact of the spread of Phragmites on the distribution of birds in Connecticut tidal marshes. Wetlands 19:194-208

Bertness MD (1992) The ecology of a New England salt marsh. Am Sci 80:260-268

Broome SW, Mendelssohn IA, McKee KL (1995) Relative growth of Spartina patens (Ait.) Muhl. and Scirpus olneyi Gray occurring in a mixed stand as affected by salinity and flooding depth. Wetlands 15:20-30

Burdick DM, Mendelssohn IA, McKee KL (1989) Production and metabolism of the marsh grass Spartina patens as related to edaphic factors in a brackish, mixed marsh community in Louisiana. Estuaries 12:195-204 
Burdick DM, Buchsbaum R, Holt E (2001) Variation in soil salinity associated with expansion of Phragmites australis in salt marshes. Environ Exp Bot 46:247-261

Chalmers AG (1982) Soil dynamics and the productivity of Spartina alterniflora. In: Kennedy VS (ed) Estuarine comparisons. Academic Press, New York, p 231-242

Chambers RM, Odum WE (1990) Porewater oxidation, dissolved phosphate and the iron curtain. Biogeochemistry 10:37-52

Chambers RM, Mozdzer TJ, Ambrose JC (1998) Effects of salinity and sulfide on the distribution of Phragmites australis and Spartina alterniflora in a tidal marsh. Aquat Bot 62:161-169

Chambers RM, Meyerson LA, Saltonstall K (1999) Expansion of Phragmites into tidal wetlands of North America. Aquat Bot 64:261-273

Clevering OA, Lissner J (1999) Taxonomy, chromosome numbers, clonal diversity and population dynamics of Phragmites australis. Aquat Bot 64:185-208

Cline JD (1969) Spectrophotometric determination of hydrogen sulfide in natural waters. Limnol Oceanogr 14: $454-458$

Emery NC, Ewanchuk PJ, Bertness MD (2001) Competition and salt-marsh zonation: stress tolerators may be dominant competitors. Ecology 82:2471-2485

Gosselink JG, Turner RE (1978) The role of hydrology in freshwater wetland ecosystems. In: Good RE, Whigham DF, Simpson RL (eds) Freshwater wetlands: ecological processes and management potential. Academic Press, New York, p 63-78

Harvey JW, Germann PF, Odum WE (1987) Geomorphological controls of subsurface hydrology in the creekbank zone of tidal marshes. Estuar Coast Shelf Sci 25:677-691

Harvey JW, Chambers RM, Hoelscher JR (1995) Preferential flow and segregation of porewater solutes in wetland sediment. Estuaries 18:568-578

Hellings SE, Gallagher JL (1992) The effects of salinity and flooding on Phragmites australis. J Appl Ecol 29:41-49

Howes BL, Dacey JWH, Goehringer DD (1986) Factors controlling the growth form of Spartina alterniflora: feedbacks between above-ground production, sediment oxidation, nitrogen and salinity. J Ecol 74:881-898

Joye SB, Hollibaugh JT (1995) Influence of sulfide inhibition of nitrification on nitrogen regeneration in sediments. Science 270:623-625

Koch MS, Mendelssohn IA (1989) Sulphide as a soil phytotoxin: differential responses in two marsh species. J Ecol 77:565-578

Koch MS, Mendelssohn IA, McKee KL (1990) Mechanism for

Editorial responsibility: Ronald Kneib (Contributing Editor), Sapelo Island, Georgia, USA the hydrogen sulfide-induced growth limitation in wetland macrophytes. Limnol Oceanogr 35:399-408

Koppitz H (1999) Analysis of genetic diversity among selected populations of Phragmites australis world-wide. Aquat Bot 64:209-222

Levine JM, Brewer JS, Bertness MD (1998) Nutrients, competition and plant zonation in a New England salt marsh. J Ecol 86:125-136

Lissner J, Schierup H (1997) Effects of salinity on the growth of Phragmites australis. Aquat Bot 55:247-260

Marks M, Lapin B, Randall J (1994) Phragmites australis (P. communis): threats, management, monitoring. Nat Areas J 14:285-294

Meyerson LA, Chambers RM, Vogt KA (1999) The effects of Phragmites removal on nutrient pools in a freshwater tidal marsh ecosystem. Biological Invasions 1:129-136

Meyerson LA, Saltonstall K, Windham L, Kiviat E, Findlay S (2000) A comparison of Phragmites australis in freshwater and brackish marsh environments in North America. Wetl Ecol Manag 8:89-103

Odum WE, Odum EP, Odum HT (1995) Nature's pulsing paradigm. Estuaries 18:547-555

Osgood DT, Yozzo DJ, Chambers RM, Jacobson D, Hoffman T, Wnek J (in press) Tidal hydrology and habitat utilization by resident nekton in Phragmites and non-Phragmites marshes. Estuaries

Parsons TR, Maita Y, Lalli CM (1984) A manual of chemical and biological methods for seawater analysis. Pergamon Press, New York

Roman CT, Niering WA, Warren RS (1984) Salt marsh vegetation change in response to tidal restriction. Environ Manag 8:141-150

Templer P, Findlay S, Wigand C (1998) Sediment chemistry associated with native and non-native emergent macrophytes of a Hudson River marsh ecosystem. Wetlands 18: 70-78

Warren RS, Fell PE, Grimsby JL, Buck EL, Rilling GC, Fertik RA (2001) Rates, patterns and impacts of Phragmites australis expansion and effects of experimental Phragmites control on vegetation, macroinvertebrates, and fish within tidelands of the lower Connecticut River. Estuaries 24: 90-107

Weinstein MP, Balletto JH (1999) Does the common reed, Phragmites australis, affect essential fish habitat? Estuaries 22:793-802

Windham L, Lathrop R (1999) Effects of Phragmites australis (common reed) invasions on above-ground biomass and soil properties in brackish tidal marsh of the Mullica River, New Jersey. Estuaries 22:927-935

Submitted: December 7, 2001; Accepted: April 15, 2002 Proofs received from author(s): July 30, 2002 